\title{
Tüberküloz kontrol programı kapsamında il değerlendirmesi
}

\author{
Tarkan ÖZDEMIR ${ }^{1}$ \\ Mustafa H. TÜRKKANI ${ }^{2}$ \\ Leyla YILMAZ AYDIN ${ }^{3}$ \\ Çiğdem BALCI \\ Rabia DANACI BAŞ ${ }^{4}$ \\ Adem BíLGiN ${ }^{5}$
}

\footnotetext{
${ }^{1}$ Çorum Göğüs Hastalıkları Hastanesi, Göğüs Hastalıkları Bölümü, Çorum, Türkiye

${ }^{1}$ Department of Chest Diseases, Corum Chest Diseases Hospital, Corum, Turkey

2 Ankara Fizik Tedavi ve Rehabilitasyon Eğitim ve Araştırma Hastanesi, Ankara, Türkiye

${ }^{2}$ Ankara Physical Therapy and Rehabilitation Training and Research Hospital, Ankara, Turkey

${ }^{3}$ Abant İzzet Baysal Üniversitesi Tıp Fakültesi, Gögüs Hastalıkları Anabilim Dalı, Düzce, Türkiye

${ }^{3}$ Department of Chest Diseases, Faculty of Medicine, Abant Izzet Baysal University, Duzce, Turkey

${ }^{4}$ Çorum Verem Savaş Dispanseri, Çorum, Türkiye

${ }^{4}$ Corum Tuberculosis Dispensary, Corum, Turkey

${ }^{5}$ Çorum Devlet Hastanesi, Sağlık Müdürlüğü, Çorum, Türkıye

${ }^{5}$ Corum State Hospital, Health Board, Corum, Turkey
}

\section{ÖZET}

\section{Tüberküloz kontrol programı kapsamında il değerlendirmesi}

Giriş: Bu çalışmada, Çorum ilinde tüberkülozun durumunu ortaya çıkarmak, tüberküloz kontrol kapsamında il düzeyinde yürütülen çalışmaları analiz etmek, gelecekte dispanser çalışmalarına ve tüberküloz kontrolüne katkı sağlamak amaçlanmıştır.

Materyal ve Metod: Çorum ilinde verem savaşı dispanserlerinde 2005-2010 yılları arasında takip ve tedavi edilen hasta kayıtları retrospektif olarak incelenmiştir. Verilerin istatistiksel analizi SPSS 16.0 programı ile yapılmıştır.

Bulgular: Toplam 628 hastanın \%59.8 ( $n=376)^{\prime}$ 'i erkek, \%40.2 ( $\left.n=252\right)^{\prime}$ si kadındır. Hastaların \%63.7 ( $\left.n=400\right)^{\prime}$ si akciğer tutulumu, \%36.3 ( $n=228$ )'ü akciğer dışı organ tutulumu göstermiştir. Yeni olguların oranı \% $93.5(n=587)$ iken önceden tedavi görmüş olguların oranı \%6.5 ( $n=41)^{\prime}$ tir. Hastaların \%0.7 $(n=4)^{\prime}$ si çok ilaca dirençli olup ikinci grup ilaç tedavisi almıştır. Akciğer tüberkülozu olan 400 hastada yapılan bakteriyolojik tetkikler incelendiğinde; mikroskop i yapılma oranı \%85.5 (n= 334), mikroskopi pozitiflik oranı \% 44.5 ( $n=178)$; kültür yapılma oranı \%66 ( $n=264)$, kültür pozitiflik oranı \%35 ( $n=140)$; ilaç duyarlılık testi yapılma oranı ise \% $15(n=60)$ bulunmuştur. Hastaların \%49.7 ( $n=312)$ 'sine doğrudan gözetimli tedavi sağlık personelince uygulanmıştır. Tüm tüberküloz hastalarında tedavi başarısı \%93.8 ( $n=576)$ olarak tespit edilmiştir.

Sonuç: Tüberküloz verileri Çorum'da başarılı bir kontrol programının yürütüldügüüü göstermektedir. Ancak tüberküloz kontrolünde eksikler bulunmaktadır. Hastaların büyük çoğunluğunun genç yaşta olması bulaşın devam ettiğini göstermektedir. Akciğer tüberkülozlu hastalarda mikroskopi, kültür ve ilaç duyarlılık testi yapılma oranları düşük bulunmuştur. Doğrudan gözetimli tedavi uygulamaları geliştirilmelidir.

Anahtar kelimeler: Tüberküloz, kontrol

\section{Yazışma Adresi (Address for Correspondence)}

Dr. Tarkan ÖZDEMiR

Elazığ Kamu Hastaneleri Birliği, ELAZIĞ - TURKEY

e-mail: tabiptarkan@hotmail.com 


\section{SUMMARY}

\section{Provincial assessment in the scope of the tuberculosis control program}

Introduction: We aimed to expose the status of tuberculosis in Corum, to analyze the conducted studies about the tuberculosis control on provincial basis and contribute to future studies.

Materials and Methods: The records of the patients who were followed and treated between 2005 and 2010 at tuberculosis dispensary in Corum were respectively investigated. The statistical analyses of the data were completed as using SPSS 16.0.

Results: A total of 628 patients were enrolled in this study; $59.8 \%(n=376)$ were male, $40.2 \%(n=252)$ were female. The ratio of the pulmonary and the extrapulmonary involvement were detected as $63.7 \%(n=400)$ and $36.3 \%(n=228)$ respectively. The incidence of new cases was $93.5 \%(n=587)$ whereas the percentage of previously treated cases was $6.5 \%(n=41)$. The $0.7 \%(n=4)$ percentage of the patients were multi-drug resistant therefore they had been treated with secondary group of drugs. 400 patients with pulmonary tuberculosis were investigated about the ratios of the following parameters; performed microscopic examination, the positivity of the microscopic examination, the performed culture examination, the positivity of the culture examination and the performed drug susceptibility test. According to this; the results were determined as $85.5 \%(n=334), 44.5 \%(n=178), 66 \%(n=264)$, $35 \%(n=140)$ and $15 \%(n=60)$ respectively. Directly observed treatment was performed $49.7 \%(n=312)$ of the patients by health care workers. The success of treatment for all patients with tuberculosis was determined as $93.8 \%(n=576)$.

Conclusion: According to the data of our study, we can conclude that, although there were some deficiencies about control of tuberculosis, the conducted control program was successful in Corum. However; having a large number of young patients with tuberculosis proved that the transmission was still going on. Besides; the examined tests like microscopy, culture and drug susceptibility were found low in rates. The practices of directly observed treatment should provide to be improved.

Key words: Tuberculosis, control

\section{GiRiş}

Tüberküloz, insanlık tarihi kadar eski bir hastalık olmasına rağmen hala tüm dünyada bir halk sağlığı sorunu olarak önemini korumaktadır. Dünya nüfusunun 1/3'ünün tüberküloz basili ile infekte olduğu düşünülürse sorunun ciddiyeti tam olarak anlaşılacaktır (1). 2012 yılında, yaklaşık 8.6 milyon kişide tüberküloz gelişmiş ve 1.3 milyon (320.000'i HIV pozitif) kişi bu hastalıktan ölmüştür. Tüberküloz ölümlerinin birçoğunun önlenebilir olduğu göz önüne alındığında bu durum kabul edilmez büyüklüktedir (2).

Tüberküloz kontrolü için altyapı, organizasyon, insan kaynağı, bütçe, program ve stratejik planın olması gereklidir. Ayrıca, tüberküloz epidemiyolojik karakteri gereği kısa vadede ortadan kaldırılabilecek bir hastalık değildir. Tüberküloz hastalarının tanı, tedavi ve takibindeki yetersizlik, toplum sağlığı için önemli sorunlara yol açar. Bundan dolayı tüberkülozla mücadele uzun soluklu, bütünlüklü ve iyi işleyen bir kontrol programı gerektirmektedir.

Tüberkülozla etkin mücadele edilebilmesi için bu hastalığın görüldüğü yaş grupları, sık rastlandığı bölgeler, hastaların sosyoekonomik durumları gibi epidemiyolojik özelliklerin iyi bilinmesi gerekmektedir. Tüberkülozun toplumdaki durumunu bilmek, bu hastalıkla etkin bir mücadele yapılmasını sağlamaktadır.

Dünyada tüberküloz kontrolü için Dünya Sağlık Örgütü (DSÖ) tarafından küresel bir kontrol progra- mı, Türkiye'de de aynı standartlarda ve paralelde bir tüberküloz kontrol programı uygulanmaktadır (3).

Türkiye'de tüberküloz kontrol programında uç birim verem savaşı dispanserleridir. Verem savaşı dispanserleri tüberküloz kontrol programının önemli bir birimidir. Dispanserler; tanı, tedavi, takip, hasta bildirimi, kayıt, istatistik, bağışıklama, tarama, ilaç ikmali, eğitim, propaganda faaliyetleri, koordinasyon ve danışmanlık hizmetlerini yürüten sağlık kurumlarıdır. Dispanser çalışmalarının değerlendirilmesi önem taşımaktadır.

Bu çalışmada; Çorum ili dispanserlerine 2005-2010 yılları arasında kayıtlı tüberküloz olgularının özelliklerini ve tüberküloz kontrol kapsamında yapılan çalışmaları değerlendirerek il düzeyinde tüberküloz hastalığının durumunu ortaya çıkarmak, tüberküloz kontrol kapsamında il düzeyinde yürütülen çalışmaları analiz etmek, gelecekte dispanser çalışmalarına ve tüberküloz kontrolüne katkı sağlamak amaçlanmıştır.

\section{MATERYAL ve METOD}

Çorum ilinde verem savaşı dispanserlerinde 20052010 yılları arasında takip ve tedavi edilen 628 hasta kayıtları retrospektif olarak incelenmiştir. 2007 yılında İskilip Verem Savaşı Dispanseri, 2008 yılında Sungurlu Verem Savaşı Dispanseri birinci basamağa entegre edilmiştir $(4,5)$. Bu dispanserlerin hasta dosyaları Çorum Merkez Verem Savaşı Dispanseri'ne aktarılmıştır. Çalışmamıza bu dispanserlerin hastaları dahil edilmiştir. Dolayısıyla çalışmada yer alan hasta- 
lar Çorum ilinin genelini temsil etmektedir. Verilerin istatistiksel analizi SPSS 16.0 programı ile yapılmıştır.

\section{BULGULAR}

Hastaların \%59.8 ( $\mathrm{n}=376)^{\prime} \mathrm{i}$ erkek, \%40.2 $\quad(\mathrm{n}=$ $252)^{\prime}$ si kadındır, erkek/kadın oranı 1.5'tir (Tablo 1).

Hastaların \%16.6 ( $\mathrm{n}=104)^{\prime} \mathrm{sı}$ okuryazar değildi, $\% 13.4(n=84)^{\prime} \ddot{u}$ lise ve üstü okul mezunuydu. Hastaların \%73.2 ( $\mathrm{n}=460)^{\prime}$ si evliydi.

Hastaların \%95.7 ( $\mathrm{n}=601)^{\prime}$ si şikayet nedeniyle doktora başvurma sonrası, \%2.9 (n=18)'u temaslı muayenesi sırasında, \%1.4 (n=9)'ü rapor başvurusu sonrası tanı almıştır.

Hastaların \%63.7 ( $\mathrm{n}=400)^{\prime}$ si akciğer tutulumu, \%36.3 ( $n=228)^{\prime} \ddot{u}$ akciğer dışı organ tutulumu göstermiştir (Tablo 2).

2005-2010 yılları arasında dispansere kayıtlı hastaların yaş gruplarına göre dağılımı Tablo 3 'te yer almaktadır.

Toplam 628 hastada yeni olguların oranı \%93.5 (n= 587) iken önceden tedavi görmüş olguların oranı \%6.5 (n= 41)'tir. Önceden tedavi görmüş olguların toplam hasta içindeki oranları; \%5.7 ( $n=36)$ nüks, $\% 0.8(n=5)$ tedaviyi terkten dönen olgudur. Tedavi başarısızlığından gelen, kronik ve bilinmeyen olgu tespit edilmemiştir (Tablo 4).

Tablo 1. Yıllara göre cinsiyet dağılımı ve olgu sayıları, 2005-2010

\begin{tabular}{|lcccccc} 
& \multicolumn{2}{c}{ Erkek } & & \multicolumn{2}{c}{ Kadın } & \\
\cline { 2 - 3 } & $\mathbf{n}$ & $\mathbf{\%}$ & & $\mathbf{n}$ & $\mathbf{\%}$ & Toplam (n) \\
\hline 2005 & 81 & 62.8 & & 48 & 37.2 & 129 \\
2006 & 63 & 60.6 & & 41 & 39.4 & 104 \\
2007 & 62 & 57.4 & & 46 & 42.6 & 108 \\
2008 & 53 & 60.2 & & 35 & 39.8 & 88 \\
2009 & 62 & 58.5 & & 44 & 41.5 & 106 \\
2010 & 55 & 59.1 & & 38 & 40.9 & 93 \\
Toplam & $\mathbf{3 7 6}$ & $\mathbf{5 9 . 8}$ & & $\mathbf{2 5 2}$ & $\mathbf{4 0 . 2}$ & $\mathbf{6 2 8}$ \\
\hline & & & & & \\
\hline
\end{tabular}

Hastaların \%0.7 ( $n=4)^{\prime}$ si çok ilaca dirençli olup ikinci grup ilaç tedavi almıştır.

Akciğer tüberkülozu olan 400 hastada yapılan bakteriyolojik tetkikler incelendiğinde; mikroskopi yapılma oranı \%85.5 $(n=334)$, mikroskopi pozitiflik oranı $\% 44.5(n=178)$; kültür yapılma oranı \%66 $(n=264)$, kültür pozitiflik oranı \%35 ( $\mathrm{n}=140)$; ilaç duyarlılık testi yapılma oranı ise \%15 $(n=60)$ bulunmuştur. Yıllar içerisinde yayma yapılma oranında dalgalanmalar, kültür yapılma oranında azalma yaşanmıştır (Tablo 5).

Hastaların \%95.4 $(n=559)^{\prime}$ ünde standart tedavi rejimleri, \%4.6 $(n=69)^{\prime}$ sında ilaç yan etkisi ve doktor tercihi nedeniyle farklı tedavi rejimleri uygulanmıştır.

Hastaların \%49.7 ( $n=312)^{\prime}$ sine DGT, sağlık personeli, \%2.8 ( $n=18)^{\prime}$ ine diğer kamu görevlileri, \%32.5 $(n=204)^{\prime}$ ine hane halkı tarafından uygulanmış. Hastaların \%15 ( $\mathrm{n}=94)^{\prime}$ ine DGT uygulanmamıştır.

Verem savaşı dispanserine kaydedilen hastalardan toplam 14'ünün daha sonraki süreçlerde tüberküloz olmadığı anlaşılmıştır. Tüm tüberküloz hastalarında tedavi başarısı \%93.8 ( $\mathrm{n}=576)$ olarak tespit edilmiştir. Ölüm oranı tüm hastalarda \%4.2 (n=26) olarak saptanmıştır. Yıllara göre tedavi sonuçları incelendi-

Tablo 2. Tüberküloz olgularında hastalığın tutulum yerinin dağılımı, 2005-2010

\begin{tabular}{|lcccccc|} 
& \multicolumn{2}{c}{ Akciğer } & & \multicolumn{2}{c}{ Akciğer dışı } & \\
\cline { 2 - 3 } & $\mathbf{\%}$ & $\mathbf{n}$ & & $\mathbf{n}$ & $\mathbf{\%}$ & Toplam (n) \\
\hline 2005 & 58.9 & 76 & & 53 & 41.1 & $\mathbf{1 2 9}$ \\
2006 & 70.2 & 73 & & 31 & 29.8 & $\mathbf{1 0 4}$ \\
2007 & 68.6 & 74 & & 34 & 31.5 & $\mathbf{1 0 8}$ \\
2008 & 64.8 & 57 & & 31 & 35.2 & $\mathbf{8 8}$ \\
2009 & 59.4 & 63 & & 43 & 40.6 & $\mathbf{1 0 6}$ \\
2010 & 61.3 & 57 & & 36 & 38.7 & $\mathbf{9 3}$ \\
Toplam & $\mathbf{6 3 . 7}$ & $\mathbf{4 0 0}$ & & $\mathbf{2 2 8}$ & $\mathbf{3 6 . 3}$ & $\mathbf{6 2 8}$ \\
\hline & & & & & \\
\hline
\end{tabular}

Tablo 3. Tüberküloz olgularının yaş gruplarına göre dağılımı, 2005-2010

\begin{tabular}{|lccccccccc|}
\hline & $\mathbf{0 - 4}$ & $\mathbf{5 - 1 4}$ & $\mathbf{1 5 - 2 4}$ & $\mathbf{2 5 - 3 4}$ & $\mathbf{3 5 - 4 4}$ & $\mathbf{4 5 - 5 4}$ & $\mathbf{5 5 - 6 4}$ & $\mathbf{6 5 +}$ & Toplam \\
\hline 2005 & 3 & 7 & 21 & 22 & 17 & 21 & 14 & 24 & $\mathbf{1 2 9}$ \\
2006 & 2 & 5 & 17 & 19 & 14 & 16 & 14 & 17 & $\mathbf{1 0 4}$ \\
2007 & 3 & 5 & 17 & 15 & 18 & 13 & 20 & 17 & $\mathbf{1 0 8}$ \\
2008 & 2 & 2 & 12 & 19 & 13 & 14 & 11 & 15 & $\mathbf{8 8}$ \\
2009 & 4 & 3 & 17 & 14 & 20 & 13 & 19 & 16 & $\mathbf{1 0 6}$ \\
2010 & 1 & 4 & 7 & 19 & 14 & 20 & 11 & 17 & $\mathbf{9 3}$ \\
Toplam & $\mathbf{1 5}$ & $\mathbf{2 6}$ & $\mathbf{9 1}$ & $\mathbf{1 0 8}$ & $\mathbf{9 6}$ & $\mathbf{9 7}$ & $\mathbf{8 9}$ & $\mathbf{1 0 6}$ & $\mathbf{6 2 8}$ \\
\hline & & & & & & & & &
\end{tabular}


Tüberküloz kontrol programı kapsamında il değerlendirmesi

Tablo 4. Tüberküloz hastalarının olgu tanımına göre dağılımı, 2005-2010

\begin{tabular}{|c|c|c|c|c|c|c|c|c|c|c|}
\hline & \multicolumn{2}{|c|}{ Yeni } & \multicolumn{2}{|c|}{ Nüks } & \multicolumn{2}{|c|}{ Terkten dönen } & \multirow[b]{2}{*}{ Başarısızlıktan gelen } & \multirow[b]{2}{*}{ Kronik } & \multirow[b]{2}{*}{ Bilinmeyen } & \multirow[b]{2}{*}{ Toplam (n } \\
\hline & $\mathbf{n}$ & $\%$ & $\mathbf{n}$ & $\%$ & $\mathbf{n}$ & $\%$ & & & & \\
\hline 2005 & 119 & 92.2 & 10 & 7.8 & - & - & - & - & - & 129 \\
\hline 2006 & 97 & 93.3 & 7 & 6.7 & - & - & - & - & - & 104 \\
\hline 2007 & 103 & 95.4 & 4 & 3.7 & 1 & 0.9 & - & - & - & 108 \\
\hline 2008 & 85 & 96.6 & 1 & 1.1 & 2 & 2.3 & - & - & - & 88 \\
\hline 2009 & 97 & 91.5 & 7 & 6.6 & 2 & 1.9 & - & - & - & 106 \\
\hline 2010 & 86 & 92.5 & 7 & 7.5 & - & - & - & - & - & 93 \\
\hline Toplam & 587 & 93.5 & 36 & 5.7 & 5 & 0.8 & & & & 628 \\
\hline
\end{tabular}

Tablo 5. Toplam akciğer tüberkülozu olgularında bakteriyolojik tetkik sonuçları, 2005-2010

\begin{tabular}{|c|c|c|c|c|c|c|c|c|c|c|c|}
\hline & \multirow{2}{*}{$\begin{array}{c}\begin{array}{c}\text { Toplam akciğer } \\
\text { tüberkülozu olgusu } \\
\text { (n) }\end{array} \\
\end{array}$} & \multicolumn{2}{|c|}{$\begin{array}{c}\text { Yayma } \\
\text { yapılan }\end{array}$} & \multicolumn{2}{|c|}{$\begin{array}{c}\text { Yayma } \\
\text { pozitifliği }\end{array}$} & \multicolumn{2}{|c|}{ Kültür yapılan } & \multicolumn{2}{|c|}{$\begin{array}{c}\text { Kültür } \\
\text { pozitifliği }\end{array}$} & \multicolumn{2}{|c|}{ iDT yapılan } \\
\hline & & $\mathbf{n}$ & $\%$ & $\mathbf{n}$ & $\%$ & $\mathbf{n}$ & $\%$ & $\mathbf{n}$ & $\%$ & $\mathbf{n}$ & $\%$ \\
\hline 2005 & 76 & 73 & 96.1 & 33 & 43.4 & 67 & 88.2 & 37 & 48.7 & 7 & 9.2 \\
\hline 2006 & 73 & 65 & 89 & 30 & 41.1 & 58 & 79.5 & 26 & 35.6 & 8 & 10.9 \\
\hline 2007 & 74 & 68 & 91.9 & 45 & 60.8 & 54 & 73 & 32 & 43.2 & 9 & 12.1 \\
\hline 2008 & 57 & 44 & 77.2 & 25 & 43.9 & 22 & 38.6 & 11 & 19.3 & 9 & 15.8 \\
\hline 2009 & 63 & 41 & 65.1 & 23 & 56.1 & 30 & 47.6 & 18 & 28.6 & 13 & 20.6 \\
\hline 2010 & 57 & 43 & 75.4 & 22 & 51.2 & 33 & 57.9 & 16 & 28 & 14 & 24.5 \\
\hline Toplam & 400 & 334 & 83.5 & 178 & 44.5 & 264 & 66 & 140 & 35 & 60 & 15 \\
\hline
\end{tabular}

ğinde tedavi başarısının yüksek olduğu (2005 yılında \%92.1, 2006 yılında \%89.9, 2007 yılında \%96.3, 2008 yılında \%94.2, 2009 yılında \%93.2, 2010 yılında \%97.8) görülmektedir (Tablo 6).

Yayma pozitif akciğer tüberkülozu olgularında kür oranı; \%60.1 $(n=107)$, tedavi başarısı (kür + tedavi tamamlama) oranları ise; \%93.8 $(n=167)$, tedavi terk \%1.7 (n=3), ölüm \%4.5 (n=8)'tir (Tablo 7).

Çorum, Türkiye genelinden daha düşük tüberküloz olgu hızına sahiptir (Tablo 8) (7).

\section{TARTIŞMA}

Türkiye'de tüberküloz kontrol programından Türkiye Halk Sağlığı Kurumu'na bağlı Tüberküloz Daire Başkanlığı sorumludur (6).

Türkiye'de dispanserler, Stop TB Stratejisi ve Uluslararası Tüberküloz Bakım Standartları (UTBS) esas alarak, her bireyin ya da hastanın en iyi korunma önlemlerinden, tanı ve tedaviden yararlanmasını sağlayacak ana faaliyetleri kendisi ya da diğer kurumlarında katılımı ile yapar. Dispanser sayısı her ilde en az bir tane olmak üzere belirlenir. İldeki ya da dispanser bölgesindeki olgu hızına göre yaklaşık her 500.000 nüfusa bir adet olan dispanser sayısı azaltı- labilir ya da artırılabilir. Tüberküloz kontrol hizmetlerin sunulabilmesi için dispanserde her 100 hasta için en az bir hekim ve en az iki hemşirenin çalışması sağlanır. Personel hareketlerini en aza indirecek önlemler alınır. Dispanser hekimlerinin sertifikalı eğitim programına katılması sağlanır (3).

Bir verem savaşı dispanseri; tüberküloz hastasında erken ve bakteriyoloji esaslı tanı koyulmasını, hastanın bildirimini, aile bireyleri ve yakın temaslılarının taranmasını ve gerekiyorsa koruyucu tedavisi verilmesini; tedavi başlangıcında ilaç duyarlılık testlerinin yapılmasını; hastaya standart/doğru tedavi rejiminin başlanmasını; tedavinin klinik ve radyolojik bulgular yanında bakteriyolojik takibini; tedavisi süresince bütün ilaç dozlarının gözetimli olarak içirilmesinin sağlanmasını; tedaviyi sürdüren kurumlar arasında hastanın naklinin uygun bir şekilde yapılmasını ve tedavinin tamamlanmasını sağlar. Ayrıca, yıl boyunca halkı tüberküloz konusunda aydınlatma ve bilgilendirme görevinde de bulunur.

Çorum il merkezinde bir verem savaşı dispanseri yer almaktadır (7). 2007 yılında İskilip İlçesi Verem Savaşı Dispanseri, 2008 yılında Sungurlu İlçesi Verem Savaşı Dispanseri birinci basamağa entegre 
Tablo 6. Tüm tüberküloz olgularının tedavi sonuçları, 2005-2010

\begin{tabular}{|c|c|c|c|c|c|c|c|c|}
\hline & \multirow{2}{*}{$\begin{array}{c}\text { Olgu sayısı } \\
\text { (n) }\end{array}$} & \multicolumn{2}{|c|}{ Tedavi başarısı } & \multicolumn{2}{|c|}{ Tedavi Terk } & \multirow{2}{*}{$\begin{array}{c}\text { Tedavi } \\
\text { başarısızlığı }\end{array}$} & \multicolumn{2}{|c|}{ Ölüm } \\
\hline & & $\mathbf{n}$ & $\%$ & $\mathbf{n}$ & $\%$ & & $\mathbf{n}$ & $\%$ \\
\hline 2005 & 124 & 115 & 92.7 & 3 & 2.4 & - & 6 & 4.7 \\
\hline 2006 & 99 & 88 & 88.9 & 4 & 4 & - & 7 & 7.1 \\
\hline 2007 & 108 & 104 & 96.3 & - & - & - & 4 & 3.7 \\
\hline 2008 & 86 & 81 & 94.2 & - & - & - & 5 & 5.8 \\
\hline 2009 & 104 & 97 & 93.2 & 5 & 4.8 & - & 2 & 1.9 \\
\hline 2010 & 93 & 91 & 97.8 & - & - & - & 2 & 2.2 \\
\hline Toplam & 614 & 576 & 93.8 & 12 & 2 & - & 26 & 4.2 \\
\hline
\end{tabular}

Tablo 7. Yayma pozitif akciğer tüberkülozu olgularının tedavi sonuçları, 2005-2010

\begin{tabular}{|c|c|c|c|c|c|c|c|c|c|c|}
\hline & \multirow{2}{*}{$\begin{array}{c}\text { Olgu sayısı } \\
\text { (n) }\end{array}$} & \multicolumn{2}{|c|}{ Kür } & \multicolumn{2}{|c|}{$\begin{array}{c}\text { Tedavi } \\
\text { başarısı }\end{array}$} & \multicolumn{2}{|c|}{ Tedavi terk } & \multirow{2}{*}{$\begin{array}{c}\text { Tedavi } \\
\text { başarısızlığı }\end{array}$} & \multicolumn{2}{|c|}{ Ölüm } \\
\hline & & $n$ & $\%$ & $n$ & $\%$ & $\mathbf{n}$ & $\%$ & & $\mathbf{n}$ & $\%$ \\
\hline 2005 & 33 & 30 & 90.9 & 30 & 90.9 & 1 & 3 & - & 2 & 6.1 \\
\hline 2006 & 30 & 24 & 80 & 26 & 86.7 & 1 & 3 & - & 3 & 10 \\
\hline 2007 & 45 & 29 & 64.4 & 43 & 95.5 & - & - & - & 2 & 4.4 \\
\hline 2008 & 25 & 16 & 64 & 24 & 96 & - & - & - & 1 & 4.6 \\
\hline 2009 & 23 & 16 & 69.6 & 22 & 95.6 & 1 & 4.3 & - & - & - \\
\hline 2010 & 22 & 16 & 72.7 & 22 & 100 & - & - & - & - & - \\
\hline Toplam & 178 & 107 & 60.1 & 167 & 93.8 & 3 & 1.7 & - & 8 & 4.5 \\
\hline
\end{tabular}

Tablo 8. Toplam olgu hızı (yüz binde), Çorum ve Türkiye, 2005-2010 (7)

\begin{tabular}{|lcccccc|}
\hline & $\mathbf{2 0 0 5}$ & $\mathbf{2 0 0 6}$ & $\mathbf{2 0 0 7}$ & $\mathbf{2 0 0 8}$ & $\mathbf{2 0 0 9}$ & $\mathbf{2 0 1 0}$ \\
\hline Çorum & 22.7 & 18.6 & 19.6 & 16.1 & 19.6 & 17.4 \\
Türkiye geneli & 28.5 & 28.1 & 27.9 & 25.8 & 24.0 & 22.5 \\
\hline & & & & & & \\
\hline
\end{tabular}

edilmiştir (4,5). Çorum il merkezinde göğüs hastalıkları hastanesi ve devlet hastanesi bulunmaktadır. On üç ilçesinden yedisinde devlet hastanesi yer almaktadır (8). Çorum Göğüs Hastalıkları Hastanesi’nin 2011 yılı sonu itibariyle 159 toplam hasta yatağının sekizi tüberküloz hasta yatağıdır (7).

Beş yıl içerisinde saptanan tüberküloz hastaların cinsiyet dağılımı Türkiye geneli ile benzerdir; saptanan bu hastaların \%59.8'i ve Türkiye genelinde hastaların \%59.5'i erkektir (7). Tüberkülozun erkeklerde daha çok saptanmasının nedeni, erkeklerin sosyal faaliyetler içinde daha fazla bulunması olarak açıklanabilir.
Beş yıl içerisinde saptanan hastaların \%63.7'si akciğer tutulumu, \%36.3'ü akciğer dışı organ tutulumu göstermiştir. Ülke genelinde 2010 yılında hastaların \%61.1'i akciğer tutulumu, \%35.1'i akciğer dışı organ tutulumu göstermiştir (7).

Tüberkülozun genç yaş grubunda fazla olması bulaşmanın sürdüğünü gösterir. Yaşlı nüfusta hastalığın fazla olması ise geçmişteki salgının etkisiyle infekte olmuş insanların yaşlanınca hastalandığını gösterir (9). Tüberkülozun kontrol altına alınma göstergelerinden birisi yoğunlaştığı yaş grubunun giderek ileri yaşlara taşınmasıdır (10). Gelişmiş ülkelerin aksine tüberküloz kontrolünün yeterli olmaması nedeniyle insidansının yüksek olduğu bölgelerde hastalığın genç yaş grubunu etkilediği görülmektedir (11).

2005-2010 yılları arasındaki tüberküloz hastalarının yaş gruplarına göre olgu hızları incelendiğinde, hastaların büyük çoğunluğunun genç yaşta olduğu görülmektedir (Şekil 1). Bunun nedeni nüfusun büyük kısmının genç olmasından kaynaklanabilir (12). Yaş 


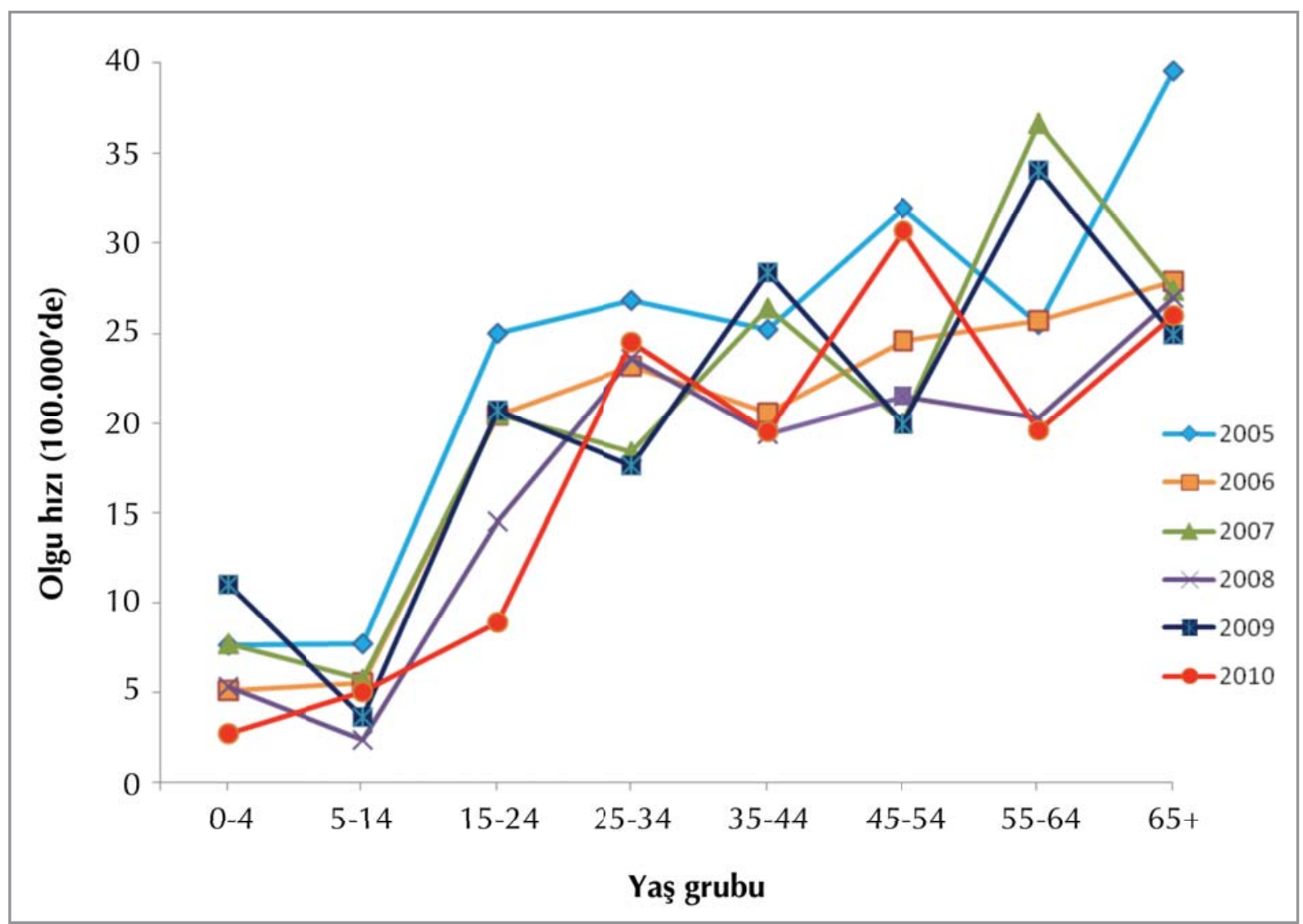

Şekil 1. Çorum'da toplam tüberküloz olgularının yaş gruplarına göre olgu hızları; 2005-2010.

gruplarına göre olgu hızları grafiğine bakıldığında 15-24 yaş grubunda ani artışın olduğu, sonraki yaş gruplarında dalgalanmalarla birlikte artışın devam ettiği görülmektedir. Özellikle 2005 yılı olgu hızı iyi kontrol programı uygulayan, insidansı düşük ve hastalığın ileri yaşlarda görüldüğü ülkelerle, yüksek insidanslı ve hastalığın genç erişkinlerde görüldüğü ülkeler arasında bir konuma benzemektedir. Bu durum, Çorum'da hem tüberküloz salgınının kısmen sürdüğünü hem de yaşlılarda artış nedeniyle tüberküloz kontrolünde belirli bir başarı olduğunu ve bir geçiş dönemi yaşandığını göstermektedir. 2010 yılında diğer yıllardan farklı olarak olgu hızında ani artış 25-34 yaş grubuna kaymıştır. Ülke genelinde 2010 yılı hastaları olgu hızının yaş gruplarına dağılımı incelendiğinde, 15-24 yaş grubundan başlayarak yükseldiği, 65 ve üzeri yaşlarda en yüksek düzeye ulaştığı görülmektedir (7).

Toplam 628 hastada yeni olguların oranı \%93.5 iken önceden tedavi görmüş olguların oranı \%6.5'tir. Önceden tedavi görmüş olguların toplam hasta içindeki oranları; $\% 5.7$ nüks, $\% 0.8$ tedaviyi terkten dönen olgudur. Tedavi başarısızlığından gelen, kronik ve bilinmeyen olgu tespit edilmemiştir. Ülke genelinde ise 2010 yılında toplam 16.551 hastada yeni olguların oranı \%91.7 iken önceden tedavi görmüş olguların oranı \%8.3; önceden tedavi görmüş olguların toplam hasta içindeki oranları; \% 6.5 nüks, $\% 1.1$ tedaviyi terkten dönen, $\% 0.5$ tedavi başarısızlığından gelen ve \%0.2 kronik olgudur (7). Tedavi başarısızlığından gelen ve kronik olguların bulunmaması, çok ilaca dirençli hasta sayısının düşük olmasından dolayı Çorum ilinde başarılı bir programın yürütüldüğü düşünmekteyiz.

Tüberküloz bir infeksiyon hastalığıdır. Tüberkülozun tanısı bakteriyolojiktir. Tüberküloz hastalarına tanıyı bakteriyolojik olarak koyulmaya çalışılmalıdır. Yayma mikroskopisi yapılan her materyali kültüre ekilmeli ve kültürde üreyen ilk materyalde ilaç duyarlılık testi yapılmalıdır (3). Akciğer tüberkülozu 400 hastada yapılan bakteriyolojik tetkikler incelendiğinde; mikroskopi yapılma oranı \%85.5, mikroskopi pozitiflik oranı \%44.5; kültür yapılma oranı \%66; kültür pozitiflik oranı \%35; ilaç duyarlılık testi yapıl- 
ma oranı ise \%15 bulunmuştur. il düzeyinde bakteriyolojik tanı koymadaki bu eksiklikler giderilmelidir. Tüberküloz hastalarının tanısını bakteriyolojik olarak koymak için 24 saat içinde mikroskobi sonucunun verildiği, mikroskobi yapılan her materyalin kültüre ekildiği, kültürde üreme olan materyallerin duyarlılık testi yapıldığı yapı oluşturulmalıdır. Ülke geneli değerlendirildiğinde; 2008 yılı kayıtlı akciğer tüberküloz hastalarında yılında bakteriyolojik tetkiklerden mikroskopi yapılma oranı \%89.1, mikroskopi pozitiflik oranı \%63; kültür yapılma oranı \%62.8, kültür pozitiflik oranı \%51.1; ilaç duyarlılık testi yapılma oranı \%26.9'dur (13).

2003 yılında "Türkiye'de Tüberkülozun Kontrolü İçin Başvuru Kitabı" yayımlanmıştır. Bu kitap, tüm sağlık kurum ve kuruluşlarında çalışan hekimler için bir başvuru kaynağı olmuştur. Bu başvuru kitabı, ülke genelinde tanı, tedavi ve takip konusunda standardın oluşmasını sağlamıştır. Kontrol programının kontrolünü bozan farklı uygulamalara son verilmesini sağlayarak tüm birimleri aynı bilinç, standartlar ve disiplinle koordinasyon halinde çalışmaya sevk etmiştir. Bu durumun yansıması olarak 5 yıl içerisinde saptanan tüberküloz, hastaların \%95.4'ünde standart tedavi rejimleri, \%4.6'sında ilaç yan etkisi ve doktor tercihi nedeniyle farklı tedavi rejimleri uygulanmıştır.

Hastaların \%85'ine DGT uygulanmıştır. DGT uygulamaları geliştirilmeli, kalitesi artırılmalıdır. Hane halkı ile yapılan DGT oranları azaltılarak sağlık görevlileri tarafından yapılan DGT oranları artııılmalıdır. DGT uygulamasını daha net değerlendirmek için hastalarla birebir anket uygulayarak geniş kapsamlı saha araştırması yapılması gerektiğini düşünmekteyiz.

Tüberküloz hastalarını iyileştirmek, yaşam kalitesini artırmak ve üretkenliklerini sağlamak; aktif tüberküloz hastalığı ya da geç etkilerinden dolayı hastanın ölümünü önlemek amaçlanmalıdır. Saptanan her bir tüberküloz hastasının kür ya da tedavi başarısı sağlanana kadar tedavisi izlenmelidir (3). 2005-2010 yıllarındaki tüm tüberküloz hastalarında tedavi başarısı \%93.8, ölüm oranı \%4.2 olarak saptanmıştır. Yıllara göre tedavi sonuçları incelendiğinde tedavi başarısının yüksek olduğu görülmektedir. Ülke geneli değerlendirildiğinde; verem savaşı dispanserlerine 2009 yılında kaydedilen tüm tüberküloz hastalarında tedavi başarısı \%89.7, ölüm oranı \%3.1 olarak saptanmıştır (7).

2005-2010 yıllarındaki yayma pozitif akciğer tüberkülozu olgularında kür oranı \%60.1; tedavi başarısı (kür + tedavi tamamlama) oranı \%93.8'dir. Ülke geneli değerlendirildiğinde; dispanserlere 2009 yılında kaydedilen yayma pozitif akciğer tüberkülozu olgularında kür oranı \%58.5, tedavi başarısı oranı \%88.5'tir (7).

Çalışmamızın bazı sınırlılıkları bulunmaktadır. Çalışma retrospektif yapıldığından yıllar içinde sağlık personeli ve dispanser değişikliklerinin veri değişikliklerine etkileri net olarak belirlenememiştir. DGT verileri dispanser kayıtlarına göre verilmiştir. Özellikle sağlık personeli tarafından yapılmayan DGT uygulamalarının güvenilirliği kesin değildir. Hastalarla birebir anket uygulayarak geniş kapsamlı saha araştırması yapılması gerektiğini düşünmekteyiz.

\section{SONUÇ}

Yıllar içerisinde olgu sayısının ve olgu hızının azalması, tedavi başarısızlığından gelen ve kronik olguların bulunmaması, çok ilaca dirençli hasta sayısının düşük olması, tedavi başarısının yüksek olması Çorum'da başarılı tüberküloz kontrol programı yürütüldüğünü göstermektedir. Ancak kontrol programında eksiklik bulunmaktadır. Hastaların büyük çoğunluğunun genç yaşta olması bulaşın devam ettiğini göstermektedir. Akciğer tüberkülozu hastalarda yapılan bakteriyolojik tetkikler incelendiğinde; mikroskopi, kültür ve ilaç duyarlılık testi yapılma oranları düşük bulunmuştur. il düzeyinde bakteriyolojik tanı koymada ki bu düşüklük giderilmeli, tanı ve tedavi takibinde bakteriyolojik yöntemlerden yeterince yararlanılmalıdır. DGT uygulamaları geliştirilmelidir. Hane halkı ile yapılan DGT oranları azaltılarak sağlık görevlileri tarafından yapılan DGT oranları artırılmalıdır. DGT uygulamasını daha net değerlendirmek için geniş kapsamlı saha araştırması yapılmalıdır. Tüberküloz kontrolünün daha ileriye götürülebilmesi için tüm dispanserlerde belirli ve aynı standartlarda faaliyetlerin yürütülmesi gerektiğini düşünmekteyiz.

\section{ÇIKAR ÇATIŞMASI}

Bildirilmemiştir.

\section{KAYNAKLAR}

1. World Health Organization: Treatment of Tuberculosis. Guidelines for National Programmes. Geneva, 1997.

2. World Health Organization. Global tuberculosis report 2013. Geneva, Switzerland: WHO, 2013.

3. Tüberküloz Tanı ve Tedavi Rehberi, Ankara: T. C. Sağlık Bakanlığı, 2011.

4. Gümüşlü F, Özkara Ş, Özkan S, Baykal F, Güllü Ü. Türkiye'de Verem Savaşı 2008 Raporu, Ankara: Türkiye Cumhuriyeti Sağlık Bakanlığı, 2008. 
5. Bozkurt H, Türkkanı MH, Musaonbaşıŏglu S, Güllü Ü, Baykal F, Hasanoğlu HC, Özkara Ş. Türkiye'de Verem Savaşı 2009 Raporu, Ankara: Türkiye Cumhuriyeti Sağlık Bakanlığı, 2009.

6. http://www.thsk.saglik.gov.tr Erişim tarihi:11 Mart 2014.

7. Musaonbaşıoğlu S, Yıldırım A, Mutlu SM, Baykal F. Türkiye'de Verem Savaşı 2012 Raporu, Ankara: Türkiye Halk Sağ/ığı Kurumu, 2013.

8. http://www.corumkhb.gov.tr Erişim tarihi: 11 Mart 2012.

9. Özkara Ş. Türkiye'de Tüberküloz Epidemiyolojisi. Özkara Ş, Kılıçaslan Z (editörler). Tüberküloz. Istanbul: Toraks Kitapları 2010:36-47.
10. Koç HA, Karagöz T. Tüberkülozda epidemiyolojik ölçütler ve yaş grupları analizi. Solunum Hastalıkları 1997;8:62134.

11. Dye C. Global epidemiology of tuberculosis. Lancet 2006;367:938-40.

12. http://www.tuik.gov.tr Erişim tarihi:10 Mart 2014.

13. Bozkurt H, Türkkanı MH, Musaonbaşığlu S, Yıldırım A, Baykal F, Özkara Ş. Türkiye'de Verem Savaşı 2010 Raporu, Ankara: Türkiye Cumhuriyeti Sağlık Bakanlı̆̆ı, 2010. 